\title{
ОСОБЛИВОСТІ СТРУКТУРИ ВНУТРІШНЬОЇ КАРТИНИ ЗДОРОВ'Я ДІТЕЙ ХВОРИХ НА ЕПІЛЕПСІЮ
}

\author{
Удк: $371.78:$ 616.853-053.2/.5
}

\section{Дзюбинсъка Марія Ярославівна}

\begin{abstract}
Аспірант кафедри загальної та клінічної психології Прикарпатського наџіонального університету імені Василя Стефаника, Івано-Франківськ (Украӥна)
\end{abstract}

\begin{abstract}
Анотація. У статті здійснено аналіз різних підходів до розуміння структури внутрішньої картини здоров'я (ВКЗ). ВКЗ являє собою комплексне суб 'єктивне уявлення людини про своє здоров'я, механізми його формування, причини погіршення, сукупність емоційних переживань у стані здоров'я, способи його підтримки і збереження, щзо включає взаємопов 'язані структурні компоненти. Визначено, що внутрішня картина здоров'я дітей хворих на епілепсію найкраще виражається через поведінковий, емоційний, когнітивний та ціннісно-мотиваційний компоненти. На рівні кожного з компонентів відображені суб'єктивні образи здоров'я особистості. Також у роботі розкрито психологічні особливості прояву кожного із ичих компонентів у дітей хворих на епілепсію. Встановлено, щзо ставлення дитини до свого здоров'я це частина ї̈ Я-концеепиї̈. Уявлення та прийняття себе у теперішньому, усвідомлення можливості розвитку у майбутньому, в умовах хвороби, є визначальними у формуванні структури внутрішньої картини здоров'я дітей хворих на епілепсію.
\end{abstract}

Ключові слова: Внутрішня картина здоров'я, структура внутрішньої картини здоров'я, поведінковий компонент, емоційний компонент, когнітивний компонент, ціннісномотивачійний компонент.

Постановка проблеми. Дослідження психологічних особливостей дітей хворих на епілепсію є надзвичайно актуальним та перспективними для медичної психології. Сприйняття пацієнтами свого здоров'я, їх суб'єктивні оцінки вважаються одними 3 найважливіших для визначення результативності у процесі контролю і подолання хвороби [11].

Обов'язковим фактором вивчення про- блеми відношення людини до свого здоров'я $€$ формування внутрішньої картини здоров'я (ВКЗ) - особливого ставлення до здоров'я, що виражається в усвідомленні його цінності, і активно-позитивному прагнення до його вдосконалення [1].

Внутрішня картина здоров'я формується у процесі особистого розвитку, і є комплексом емоційних переживань, відчуттів, поведі- 
нкових реакцій та уявлень людини про здоров’я. Як підкреслює В. А. Ананьєв, у ній наявні всі три складові структури особистості: когнітивна, емоційна та поведінкова [1].

У дітей з епілепсією відзначаються виражені емоційні порушення адаптивних можливостей особистості та порушення міжособистісних взаємин, що виявляються в підвищеній дратівливості, чутливості, та слабкій керованості хворих. Це призводить до проблеми спілкування у дітей та підлітків з епілепсією у сім'ї та школі. (А. І. Болдирев, 1990; Д. Н. Ісаєв， 2001; $\quad$ В. В. Ковальов， 1995; О. В. Кербіков, 1965).

Як стверджує Л. А. Троїцька, у дітей 3 епілепсією спостерігаються індивідуальні особливості характеру, які розвинулися внаслідок хвороби та ставлення соціального оточення. Незважаючи на це, емоційно-особистісні особливості хворих на епілепсію практично не досліджувалися психологами.

Мета нашого дослідження - визначення структури внутрішньої картини здоров'я дітей, які страждають епілепсією.

Відповідно до поставленої мети нами були сформовані такі завдання:

проаналізувати сутність феномену «внутрішня картина здоров'я»;

здійснити теоретичний аналіз підходів до структури ВКЗ;

дослідити особливості структури ВКЗ дітей хворих на епілепсію.

ВКЗ дітей 3 епілепсією формується 3 ранніх етапів онтогенетичного розвитку в ході їх соціалізації. Отже, на думку В. А. Ананьєва, існують реальні можливості коректного втручання у процес виховання хворих дітей, для чого необхідно вивчати структуру ВКЗ [1].

Про значення виокремлення компонентів структури внутрішньої картини здоров'я як у дорослих, так і у дітей наголошує Г. С. Нікіфоров. Когнітивний рівень ВКЗ, на його думку, передбачає уявлення дитини про стан здоров'я, що в значній мірі залежить від іiї віку та рівня розвитку інтелекту. Орієнтуючись на концепцію Р. Бернса, даний компонент включає в себе знання дитини про свої можливості, в тому числі і фізичні. Це і сприйняття дитиною свого зовнішнього вигляду, свого тіла, своїх фізичних якостей (сила, витривалість, спритність та ін.). Когнітивний компонент не тільки формує уявлення дитини про себе, а й включає ставлення до себе, відображає рівень самоповаги. Розвиток цього компонента образу «Я» в значній мірі залежить від соціального оточення дитини, особливостей ï виховання і життєвого досвіду.

Емоційний рівень пов'язаний з різними видами емоційного реагування на здоров'я, що визначається індивідуальнотипологічними i індивідуальнопсихологічними характеристиками дитини, а також особливостями їі емоційного реагування на різні життєві ситуації. У своїй концепції Р. Бернс виділяє емоційно-оцінний компонент 
(самооцінка), який відображає результати порівняння знань дитини про себе з іншими дітьми. Онтогенез оціночних образів «Я» пов'язаний $з$ формуванням у дитини диференційованих узагальнених знань про себе в процесі діяльності та спілкування 3 оточуючими. Афективна оцінка уявлень дитини про свої можливості може володіти різною інтенсивністю. Конкретні негативні чи позитивні характеристики образу «Я» можуть викликати у неї більш-менш сильні емоції, пов'язані з їх прийняттям або осудом.

Поведінковий рівень пов'язаний з актуалізацією діяльності дитини по збереженню здоров'я. Це найвищий рівень ставлення до здоров'я, який вимагає активної діяльності суб'єкта, спрямованої на збереження і підтримку свого здоров’я. Як вважає Р. Бернс, поведінковий компонент образу «Я» включає в себе конкретні дії, які можу бути викликані образом «Я» і самооцінкою. Це дуже важливий компонент в адаптації дитини до навколишньої дійсності [10].

Порівнюючи основні структурні складові структури внутрішньої картини здоров'я, структури внутрішньої картини хвороби (BКX) i ставлення до здоров'я, дослідниця О. І. Богучарова виділила такі сторони ВКЗ: раціональна, емоційна, чуттєва, мотиваційноповедінкова.

Раціональна сторона ВКЗ включає у себе уявлення про умови, причини, зміст, прогнози та оптимальні засоби збереження здоро- в’я. У структурі ВКХ їй відповідає інтелектуальний рівень, а у ставленні до здоров'я - когнітивна складова.

Емоційна складова у структурах ВКЗ, ВКХ та ставленні (відношенні) до здоров'я включає у себе емоції, настрої, почуття, переживання особистості стосовного свого здоров'я або хвороби.

Чуттєва сторона ВКЗ представлена сенситивним або чуттєвим рівнем у ВКХ, а у структурі ставлення до здоров'я вона відсутня. Її складають комплекс відчуттів, що формують загальне емоційне тло здорової людини, «відчуття здоров’я».

Мотиваційно-поведінкова сторона відповідає мотиваційному рівню ВКХ та поведінковій складовій ставлення (відношенні) до здоров'я. До неї належать сукупність дій, зусиль, прагнень задля суб'єктно значущих цілей [2].

Для нашого дослідження важливо розглядати ВКЗ з психологічної позиції, виокремивши три їі рівні: відчуттєвий, інтелектуальний та емоційний. Такої позиції дотримуються дослідники П. І. Сидоров і А. В. Парняков, які визначають ВКЗ як складову самосвідомості, уявлення про фізичний стан, що супроводжується своєрідним чуттєвим тлом [2].

На думку вчених М. I. Губанова i Г. І. Царегородцева, структура внутрішньої картини здоров'я $\epsilon$ аналогічною структурі внутрішньої картини хвороби, і включає в себе сенситивний, раціональний, емоційний i 
мотиваційний компоненти [3].

Можна погодитися 3 припущенням Г. Т. Красильникова, Л. М. Сича та Л. Л. Галіна про те що ВКЗ являє собою динамічну модель, в якій відображений процес діалогу людини у самосвідомості зі своїм «Я» та своїм організмом. У функціональній структурі ВКЗ автори виділяють чотири компоненти:

1.Раціонально-когнітивний (фіксує особистий досвід хвороби й одужання, а також певні теоретичні уявлення);

2.Емоційно-чуттєвий (характеризується емоційним реагуванням на прояви здоров'я);

3.Сенсорний (представлений різними сенсорними сигналами тіла,);

4.Мотиваційний (відображає потребу бути здоровим, міру відповідальності за своє здоров'я, готовність до діяльності на благо здоров'я) [4].

Дослідження В. Є. Кагана підтверджують, що особливе значення у структурі ВКЗ хворих дітей займає психосоматичний потенціал індивіда, з яким пов'язана міра і якість його здоров'я в майбутньому. Формування ВКЗ у дітей опосередковане сімейними ефектами, а також лікарським впливом. Тому, як наголошує автор, потрібно надавати великого значення діалогу ВКЗ всередині терапевтично-комунікативної системи «лікар-сім'ядитина» [5].

Сучасна дослідниця О. С. Лісова узагальнила існуючі у науковій літературі дані про структуру суб'єктивного відображення здоро- в'я і представили власну багатовимірну модель ВКЗ, компоненти якої доповнюються по мірі усвідомлення людиною свого рівня здоров'я і свого ставлення до здоров'я [8].

Таким чином, проаналізувавши основні підходи до розуміння структури ВКЗ та особливості дітей хворих на епілепсію, ми виділили наступні іiі основні компоненти для досліджуваної категорії дітей: поведінковий, емоційний, когнітивний та ціннісномотиваційний.

\section{Поведінковий компонент - моторно-} вольова сторона ВКЗ, яка являє собою конкретні дії людини, іiї зусилля, спрямовані на збереження і підтримку свого здоров'я, досягнення суб'єктивно значущих цілей.

У своєму дослідженні вчена О. С. Лісова говорить про те що так звана «схема тіла» безпосередньо впливає на формування актуального та ресурсного стану людини. Актуальний стан - це той стан, у якому індивід перебуває у конкретний момент чи відрізок часу; він визначає характерні для індивіда поставу, ходу, спосіб дихання, міміку і жести, а також звичну міру фізичної активності. Ресурсний стан - це той оптимум фізичних можливостей, на який здатна людина і який вона може відчувати [8].

\section{Досліджуючи ВКЗ у соматично хворих} дітей, В. Є. Каган дійшов висновку, що іiї особливе значення у цей віковий період полягає у визначенні великою мірою психосоматичного потенціалу індивіда, з яким пов'язана міра i 
якість його здоров'я в майбутньому. Вчений Д. М. Ісаєв, аналізуючи особливості ВКЗ дітей помітив, що діти в цілому знають про обмежені можливості збереження здоров'я, однак не мають стійких уявлень про ймовірність порушення здоров'я.

Ставлення до свого здоров'я у дітей хворих на епілепсії впливає як на клінічні прояви хвороби, так і на здатність хворих адаптуватися у соціальному середовищі. Воно визначається, в першу чергу, ставленням до себе.

Дослідження О. Ю. Раєвської підтверджують, що порушення самосвідомості як основного фактора саморегуляції спостерігається у всіх хворих на епілепсію, незалежно від форми захворювання. Вчені 3. I. Кекелідзе та Г. В. Тюменкова дійшли до висновку, що епілептикам притаманне егоцентричне сприйняття себе і свого оточення, яке проявляється у бажанні «прикрасити» себе і своє захворювання.

Варто також підкреслити, що $з$ віком і збільшенням терміну давності захворювання у хворих на епілепсію відбувається зниження рівня адекватності самооцінок. Формуючись в ранньому дитинстві, самооцінка особистості тривалий час залишається «пластичною», що дозволяє створити певні умови для іiї зміни. Тому надзвичайно важливою $€$ діагностика поведінкового компоненту ВКЗ у дітей хворих на епілепсію починаючи з раннього віку.

Емоційний компонент представлений особливостями і звичними способи пережи- вання людиною власних життєвих ситуацій та ситуацій інших людей і тим емоційним тлом, яке забарвлює іiї щоденне існування.

Емоційний компонент проявляється у особливостях і звичних способах переживання людиною власних життєвих ситуацій та ситуацій інших людей, і тим емоційним тлом, яке забарвлює її щоденне [8].

Оскільки емоції включені у всі види психічної діяльності і базуються на різноманітних потреба дітей з епілепсією, зміни емоційного стану хворих проявляються 3 раннього віку. У своїх дослідженнях Л. А. Троїцька зазначає, що поведінкові порушення та емоційні розлади наявні у $30 \%$ дітей з різними формами епілепсії вже у ранньому віці. Також, починаючи з цього періоду, у 8\% хворих спостерігається агресивна поведінка. У підлітковому віці у дітей з епілепсією проявляється роздратованість або вербальна агресія. Дослідниця А. I. Болдирєва стверджує, що тривалість даного захворювання приводить до стійких емоційно-особитісних порушень внаслідок органічного ураження ЦНС [9].

Можна погодитися $з$ думкою Л. А. Троїцької, що однією із важливих характеристик емоцій дітей з епілепсією $є$ їх взаємозв'язок 3 пізнавальною діяльністю. У будь-якій пізнавальній діяльності емоції виступають мотивуючим та регулюючим іiі компонентом в залежності від цілей, на які дана емоція направлена [9]. 


\section{Когнітивний компонент складають} знання, уявлення, переконання дітей хворих на епілепсію про здоров'я, способи його збереження та зміцнення.

Дослідник А. Дж. Крістенсен зі співавторами, проводячи валідизацію опитувальника ірраціональних думок щодо здоров'я, дійшли висновку, що високі когнітивні трансформації у бік ірраціональних думок корелюють із недостатнім досвідом здоров'я і в той же час із низьким рівнем прояву позитивних і високим - негативних емоцій [11].

Рівень знання і уявлення про здоров'я формується у процесі спілкування та взаємодії дітей хворих на епілепсією з батьками, вчителями, іншими дітьми.

Можна виділити п'ять етапів формування когнітивного компоненту ВКЗ.

Перший етап охоплює немовлячий вік. Ранні емоційні контакти у цей період здійснюють позитивний вплив на оцінку і відношення дитини до свого здоров'я в майбутньому.

На другому етапі відбувається формування ідентичності та наслідування. Він включає раннє дитинство. Важливе значення на даному етапі має модель батьківського відношення до здоров'я.

Третій етап являє собою етап конкретно-ситуативного уявлення дітей дошкільного віку про своє здоров'я. Тільки в кінці дошкільного віку у дітей спостерігаються власні уявлення про своє здоров'я.
Четвертий етап - це усвідомлення i емоційно-оціночне ставлення до свого здоров'я у молодшому шкільному віці. 3 формуванням логічного мислення розвивається усвідомлення дитиною своїх фізичних і психічних можливостей.

Становлення соціальної установки підлітка на своє здоров'я відбувається на п’ятому етапі. У цей період діти зацікавленні в об'єктивному знанні про своє здоров'я [10].

\section{Ціннісно-мотиваційний компонент}

передбачає формування у дітей, які хворіють на епілепсію, усвідомлення цінності свого здоров'я та прийняття особистої відповідальності за нього. Даний компонент виступає ядром ВКЗ, оскільки показує конкретно визначену позицію стосовно здоров'я і наявність сильного вольового потенціалу [8].

Вчені 3. І. Кекелідзе та Г. В. Тюменкова припускають, що до чинників, які сприяють соціальній адаптації хворих відносяться наявність об'єктивних знань про епілепсію, можливі наслідки ії протікання та шляхи подолання. У своїх дослідженнях вони підтверджують, що епілептики часто вважать себе винними у хворобі.

Особливостями ціннісно-мотиваційної сфери дітей з епілепсією $є$ те що вони важко переживає свою хворобу, соромляться іiї, для них характерна підвищена чутливість, вразливість, виражене відчуття своєї неповноцінності 3 прагненням до компенсації [7]. Разом 3 цим їм притаманний, так званий, 
«епілептичний оптимізм» - віра в можливість повного вилікування.

Однією з основних характеристик дітей хворих на епілепсію є егоцентризм - власне «я» завжди залишається в центрі уваги хворих, в їх висловлюваннях завжди на першому місці вони самі та їх хвороба [6]. Відзначається дуже велике прагнення до самоствердження. Епілептики схильні постійно підкреслювати позитивні сторони своєї поведінки і в той же час критикувати інших [7].

Важливий вплив для формування ціннісно-мотиваційної сфери має Я-концепція особистості, яка визначає установки, спрямовані на здоров'я. Сукупність відчуттів, уявлень та переживань дітей хворих на епілепсію 3 приводу свого фізичного стану може викривляти їх Я-образ.

Таким чином, епілептики з адекватною Я-концепцією виявляють адекватне відношення до свого здоров'я на когнітивному, емоційному, поведінковому та ціннісномотиваційному рівнях.

\section{Висновки:}

1. Внутрішня картина здоров'я дітей хворих на епілепсію найкраще виражається через поведінковий, емоційний, когнітивний та ціннісно-мотиваційний структурні компоненти. Кожен з цих компонентів має свої особливості прояву та всі вони взаємопов'язані між собою.

2. Психологічні особливості ВКЗ дітей хворих на епілепсію залежать від суб'єктив- ного відображення стану свого здоров'я, сукупності знань та уявлень про нього, а також усвідомлення його цінності. Все це значною мірою визначає психосоматичний потенціал індивіда.

3. Внутрішня картина здоров'я дітей 3 епілепсією визначається такими основними особливостями хвороби: емоційноособитісними порушеннями внаслідок органічного ураження ЦНС; підвищеною чутливість та дратівливістю; відчуттям своєї неповноцінності; прагненням до компенсації; вірою в одужання.

4. Неправильне ставлення дітей з епілепсією до своєї хвороби, невміння керувати своїми емоціями, заниження своїх можливостей може призвести до соціальної дезадатації та психологічних порушень.

На нашу думку, з'ясування характеристик кожного із компонентів ВКЗ дітей хворих на епілепсію дасть можливість здійснити психологічний аналіз їх ВКЗ в цілому, і це в свою чергу дозволить розробляти комплексні корекційні програми для цієї категорії хворих дітей, спрямовані на їх адаптацію в сім’ї та школі, а також інтеграцію в суспільство. Тому подальшу перспективу діяльності ми вбачаємо у дослідженні особливостей як окремих компонентів структури ВКЗ так і вікової динаміки розвитку ВКЗ дітей хворих на епілепсію.

\section{Перелік використаних джерел:}

1. Ананьев В. А. Психология здоровья: пути становле- 
ния новой отрясли человекознания // Психология здоровья / Под ред. Г. С. Никифорова. - СПб.: Изд-во СПбГУ, 2000. - 495с.

2. Богучарова О. I. Внутрішня картина здоров'я як умова формування особистості (спроба проблематизації) / О. І. Богучарова /368 Зб. наук. пр. Ін-ту психол. ім. Г. С. Костюка АПН України.- Т. IV.- Ч. 1.- 2002.- С. 11-20.

3. Бурлачук Л. Ф., Кочарян А. С., Жидко М. Е. Психотерапия: [учебник] / Л. Ф. Бурлачук, А. С. Кочарян, М. Е. Жидко. - 2 изд. - СПб. : Питер, 2006.- 370 с.

4. Елисеев О. П. Практикум по психологии личности / О.П. Елисеев. - 2-е изд., испр. и перераб. - СПб. : Питер, 2005. - 509 с.: ил. - Библиогр.: С. $501-508$.

5. Каган B. C. Внутренная картина здоров'я - термин или концепція? / В. С. Каган // Вопросы психологии. № 1. СПБ: Изд-во СПбГУ, 1993. - С. 124-130.

6. Киссин М. Я. Клиническая эпилептология. М.: ГЭОТАР-Медиа, 2009. 256c

7. Кононова М. П. Руководство по психологическому исследованию психически больных детей школьного возраста.- М.: Гос. изд-во медицинской литературы, 1963. C. $128-152$.

8. Лісова О. С. Психокорекція дезадаптивних типів внутрішньої картини здоров'я у хворих на виразкову хворобу // Медицинская психология. - 2008. - Т.3, № 1. C. $44-50$.

9. Троицкая Л. А. Особенности эмоциональной сферы у детей с эпилепсией. / Л. А. Троицкая // Научный журнал Известия российского государственного педагогического университета им. А.И.Герцена, 2008, № 10(57), C. $127-131$.

10. Психология здоровья: Учебник для вузов / Под ред. Г С. Никифорова. - СПб.. Питер, 2006. - 607 с.

11. Association of patient's perception of health status and exercise electrocardio-gram, myocardial perfusion imaging, and ventricular function measures / J. A. Mattera, C. M. De Leon, F. J. Wackers, C. S. Williams, Y. Wang, H. M. Krum - holz // Am Heart Journal.- 2000.- Sep; 140(3).- P. 359360 .
12. Eurenius E., Brodin N., Lindblad St. Predicting physical activity and general health perception among patients with rheumatoid arthritis // Journal of rheumatology.- 2007. - Vol. 34, № 1.- P. 10-15.

\section{References (Transliteration):}

1. Ananev $V$. A. Psihologiya zdorovya: puti stanovleniya novoy otryasli chelovekoznaniya // Psihologiya zdorovya / Pod red. G. S. Nikiforova. - SPb.: Izd-vo SPbGU, 2000. 495s.

2. Bogucharova O. I. VnutrIshnya kartina zdorov'ya yak umova formuvannya osobistostI (sproba problematizatsiyi) / O. I. Bogucharova /368 Zb. nauk. pr. In -tu psihol. Im. G. S. Kostyuka APN Ukrayini.- T. IV.- Ch. 1.- 2002.- S. 11-20.

3. Burlachuk L. F., Kocharyan A. S., Zhidko M. E. Psihoterapiya: [uchebnik] / L. F. Burlachuk, A. S. Kocharyan, M. E. Zhidko. - 2 izd. - SPb. : Piter, 2006.$370 \mathrm{~s}$.

4. Eliseev O. P. Praktikum po psihologii lichnosti / O.P. Eliseev. - 2-e izd., ispr. i pererab. - SPb. : Piter, 2005. 509 s.: il. - Bibliogr.: S. $501-508$.

5. Kagan V. S. Vnutrennaya kartina zdorov'ya - termin ili kontseptsIya? / V. S. Kagan // Voprosyi psihologii. - \# 1. SPB: Izd-vo SPbGU, 1993. - S. 124-130.

6. Kissin M. Ya. Klinicheskaya epileptologiya. M.: GEOTAR-Media, 2009. 256s

7. Kononova M. P. Rukovodstvo po psihologicheskomu issledovaniyu psihicheski bolnyih detey shkolnogo vozrasta.- M.: Gos. izd-vo meditsinskoy literaturyi, 1963. S. $128-152$.

8. Lisova $O$. S. Psihokorektsiya dezadaptivnih tipiv vnutrishnoyi kartini zdorov'ya u hvorih na virazkovu hvorobu // Meditsinskaya psihologiya. - 2008. - T.3, \# 1. S. $44-50$.

9. Troitskaya L. A. Osobennosti emotsionalnoy sferyi u detey s epilepsiey. / L. A. Troitskaya // Nauchnyiy zhurnal Izvestiya rossiyskogo gosudarstvennogo pedagogicheskogo universiteta im. A.I.Gertsena, 2008, \# 10(57), S. 127-131. 
10. Psihologiya zdorovya: Uchebnik dlya vuzov / Pod red. G S. Nikiforova. — SPb.. Piter, 2006. - 607 s.

11. Association of patient's perception of health status and exercise electrocardio $\neg$ gram, myocardial perfusion imaging, and ventricular function measures / J. A. Mattera, C. M. De Leon, F. J. Wackers, C. S. Williams, Y. Wang, H. M. Krum - holz // Am Heart Journal.- 2000.- Sep; 140(3).R. 359-360.;

12. Eurenius E., Brodin N., Lindblad St. Predicting physical activity and general health perception among patients with rheumatoid arthritis // Journal of rheumatology.- 2007.- Vol. 34, \# 1.- P. 10-15.

\section{Dzyubynska Maria}

PhD student at Vasyl Stefanyk Precarpathian National University, Ivano-Frankivsk (Ukraine)

\section{FEATURES OF THE STRUCTURE OF THE INNER HEALTH LOOK OF THE CHILDREN WITH EPILEPSY}

\section{ABSTRACT}

The article analyzes different approaches to understanding the structure of inner health look. Inner health look is a complete human subjective understanding of their health, mechanisms of its formation, the causes of deterioration, a set of emotional experiences in health, and ways to support conservation, including the interrelated structural components. It was determined that the inner health look of children with epilepsy is best expressed through behavioral, emotional, cognitive and valuemotivational components. The behavioral component - motor-willed party of inner health look, which is a specific human action, its efforts to preserve and maintain their health, achievement subjectively meaningful goals. The emotional component is represented features and traditional way of man experiencing their own situations and situations of others and the emotional backdrop that colors its daily life. Cognitive component are knowledge, ideas, beliefs, children with epilepsy health, ways to preserve and strengthen. The level of knowledge and understanding of health formed in the process of communication and interaction between children with epilepsy with parents, teachers and other people. Value-motivational component involves the formation of children who suffer from epilepsy awareness of the value of their health and acceptance of personal responsibility for him. This component acts as the core structure of inner health look as it shows a specified position on health and the potential presence of a strong willed. At the level of each component reflected images subjective health of the individual. Also disclosed in the psychological features of each of these components in children with epilepsy. Established that the child's attitude towards their health - is part of her self-concept. Submission and acceptance of yourself in the present, awareness of opportunities in the future, in terms of disease, are crucial in determining the structure of inner health look of the children with epilepsy.

Key words: inner health look, the structure of inner health look, behavioral component, emotional component, cognitive component, valuemotivational component. 


\section{Дзюбинская Мария Ярославовна}

Аспирант кафедры общей и клинической психологии Прикарпатского начионального университета имени Василия Стефаника, г. Ивано-Франковск (Украина)

\section{ОСОБЕННОСТИ СТРУКТУРЫ ВНУТРЕННЕЙ КАРТИНЫ ЗДОРОВЬЯ ДЕТЕЙ БОЛЬНЫХ ЭПИЛЕПСИЕЙ}

Аннотация. В статье проведен анализ различных подходов к пониманию структуры внутренней картины здоровья (ВКЗ). ВКЗ представляет собой комплексное субъективное представление человека о своем здоровье, механизмы его формирования, причины ухудшения, совокупность эмоциональных переживаний в состоянии здоровья, способы его поддержания и сохранения, включающий взаимосвязанные структурные компоненты. Определено, что внутренняя картина здоровья детей больных эпилепсией лучше всего выражается через поведенческий, эмоциональный, когнитивный и ценностно-мотивационный компонент компоненты. На уровне каждого из компонентов отражены субъективные образы здоровья личности. Также в работе раскрыто психологические особенности проявления каждого из этих компонентов у детей, больных эпилепсией. Установлено, что отношение ребенка к своему здоровью - это часть ее Яконцепции. Представления и принятия себя в настоящем, осознание возможности развития в будущем, в условиях болезни, являются определяющими в формировании структуры внутренней картины здоровья детей больных эпилепсией.

Ключевые слова: внутренняя картина здоровья, структура внутренней картины здоровья, поведенческий компонент, эмоциональный компонент, когнитивный компонент, ценностно-мотивационный компонент.
Дата отримання статті: 15.04.2017

Дата рекомендації до друку: 20.04.2017 